\title{
"Talent management practices in IT companies of Ukraine: Differences in exclusive and inclusive approaches"
}

\begin{tabular}{|c|c|}
\hline AUTHORS & $\begin{array}{l}\text { Natalia Nosan (iD } \\
\text { S } \\
\text { Sergiy Nazarenko (iD) }\end{array}$ \\
\hline ARTICLE INFO & $\begin{array}{l}\text { Natalia Nosan and Sergiy Nazarenko (2021). Talent management practices in IT } \\
\text { companies of Ukraine: Differences in exclusive and inclusive approaches. } \\
\text { Problems and Perspectives in Management, 19(4), 436-445. } \\
\text { doi:10.21511/ppm.19(4).2021.35 }\end{array}$ \\
\hline DOI & http://dx.doi.org/10.21511/ppm.19(4).2021.35 \\
\hline RELEASED ON & Friday, 24 December 2021 \\
\hline RECEIVED ON & Wednesday, 10 November 2021 \\
\hline ACCEPTED ON & Friday, 17 December 2021 \\
\hline LICENSE & $\begin{array}{l}(c) \text { EY } \\
\text { This work is licensed under a Creative Commons Attribution } 4.0 \text { International } \\
\text { License }\end{array}$ \\
\hline JOURNAL & "Problems and Perspectives in Management" \\
\hline ISSN PRINT & $1727-7051$ \\
\hline ISSN ONLINE & $1810-5467$ \\
\hline PUBLISHER & LLC "Consulting Publishing Company "Business Perspectives" \\
\hline FOUNDER & LLC "Consulting Publishing Company "Business Perspectives" \\
\hline
\end{tabular}

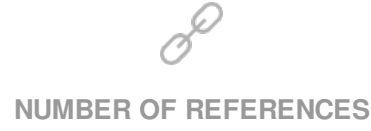

43

\section{NUMBER OF FIGURES}

0
$-=$
$z=-$

NUMBER OF TABLES

5

(C) The author(s) 2021. This publication is an open access article. 


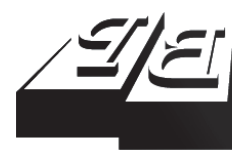

\section{BUSINESS PERSPECTIVES}

O)

LLC "CPC "Business Perspectives"

Hryhorii Skovoroda lane, 10,

Sumy, 40022, Ukraine

www.businessperspectives.org
Received on: $10^{\text {th }}$ of November, 2021 Accepted on: $17^{\text {th }}$ of December, 2021 Published on: $24^{\text {th }}$ of December, 2021

() Natalia Nosan, Sergiy Nazarenko, 2021

Natalia Nosan, D.Sc. in Economics, Associate Professor, Department of Management and Economic Security, Faculty of Economics and Law, Bohdan Khmelnytsky National University of Cherkasy, Ukraine. (Corresponding author)

Sergiy Nazarenko, D.Sc. in Economics, Professor, Head of the Department of Management and Economic Security, Faculty of Economics and Law, Bohdan Khmelnytsky National University of Cherkasy, Ukraine.

\begin{abstract}
Employees, their knowledge, and skills are becoming an increasingly important factor in the performance and competitiveness of companies in the XXI century. Approaches to talent management vary around the world. The more technological the company, the more unique the technology of using human capital and the higher the level of employee stress. The aim of the study is to establish statistically significant differences in exclusive and inclusive approaches to talent management in Ukrainian IT companies. The study employed methods of psychodiagnostic and descriptive statistics. The research period is from January to June 2021. The total number of respondents is 150 employees from the TOP-50 largest IT companies in Ukraine as of 2020. The population of the empirical study included 70 men (46.7\%) and 80 women (53.3\%) aged 21 to 40 years. The results of empirical analysis show that, indeed, the degree of employee burden in IT companies is enormous. The study empirically confirmed and theoretically proved that there are statistically significant differences in exclusive and inclusive approaches to talent management. IT companies that use an exclusive approach show burnout rates at an average level (according to $38.5 \%$ of respondents), and talents are already working at the limit of their psycho-emotional resource capabilities.
\end{abstract}

\section{Keywords competence, talent capital, innovations, creativity, IT professions, burnout}

\section{JEL Classification M12, M15}

\section{INTRODUCTION}

Nowadays, talent management should be considered not only from the business side and personnel management systems but also from the standpoint of sociology, general psychology, management psychology, even psychiatry and psychotherapy, if necessary. This is due to the fact that every month new professions appear in the world, a new set of competencies is formed, and there is an internal movement of staff like a "chessboard". Specialists of IT companies feel extremely uncomfortable due to the development and implementation of new software products, generation of new ideas following the deadlines every day, along with the ability to overcome their tension and stress (intensify coping strategies), above all, because these are top-management required skills.

Numerous surveys and studies in recent years confirmed that occupational exhaustion and systemic fears are the main sources of burnout for young employees in companies of the United States, Asia, and Europe. New professions in the IT segment are growing faster than universities have time to assign the appropriate qualifications to graduates (e.g. network lawyer, digital linguist, cyber-investigator), etc. 
An exclusive approach to talent management obviously aggravates the situation as it approaches the identification of the "just the one", the strongest training programs "for the best one", the expectations of super-profits for the company "from the very talented ones", because they are used to make large investment rates with the possibility of receiving high dividends. While $85 \%$ of employees, according to the inclusive approach to talent management, face stress due to the effect of gradual accumulation (daymonth-year), $15 \%$, following the exclusive approach of talent management, have a clear acceleration of stress and burnout (minutes-hours-months-years).

\section{LITERATURE REVIEW}

In the $21^{\text {st }}$ century, a talent management model has changed and is somewhat different from that described by Becker (1993), Watkins (1998), Michaels et al. (2001), and Schweyer (2004). Those models could not predict the pace of knowledge and innovation development boosted by the intelligence and energy of people, their willingness to act as the driving force for technical, scientific, and technological progress. The $21^{\text {st }}$ century has been marked the beginning of a new era of the rapid growth of "E-talents" on the Internet, or the pool of "freelance talents".

The term talent management was first used by Watkins (1998) who later developed the theory of talent management systems. Michaels et al. (2001) further elaborated this term. Schweyer (2004) and Lewis and Heckman (2006) have further given their critical reviews.

The common understanding of the concept of "talent" is associated with the concept of "potential" as the desire for high-level achievements (Tansley, 2011). The word "talented" is conventionally equated with the synonym gifted, extraordinary, exceptional, etc. (Chamorro-Premuzic et al., 2012). All these descriptions of talents can be divided into subcategories: abilities, non-traditional thinking, intelligence, and focus on results. Talent comprises all who do their best even if it is seemingly impossible. Talent retention strategies include a friendly environment, open teamwork, overtime compensation, succession planning, training, and development (Marinakou \& Giousmpasoglou, 2019).

In a broad sense, talent management refers to activities to attract, select, develop, and retain the best employees within the company's strategy (considering employees that are necessary to achieve the strategic priorities of the organization at the global level). A key aspect of talent management is a competitive advantage, which has brought many companies to the category of prosperous. Almost all domestic researches are focused on this aspect, considering the origins of talent management in the development of human resources theory. Among diverse terms of the scale of talent management are international, local, and regional (Vynnychuk, 2017; Kovalska \& Kovaliukh, 2019; Kuznetsova, 2014; Storozhuk \& Zaiarniuk, 2019; Shchokina et al., 2020).

There are two main approaches to talent management: 1) inclusive (Inclusive Talent Management) and 2) exclusive (Exclusive Talent Management). The difference between these approaches is that the inclusive approach is focused on the entire staff of the company because all employees are talented in their own way. The exclusive approach is based on careful identification of the most talented employee with high potential in terms of the company's business (HiPo - High Potential) (Ready, 2007; Al Ariss, 2014; Dries, 2013; Savanevičienè \& Vilčiauskaite, 2017).

According to the inclusive approach, an organization does not have a division between talented and other employees. The advantage of this approach can be manifested in the motivation of all employees at the same time. However, a negative phenomenon may not be enough for each employee, since it takes up a lot of material and time resources.

According to the exclusive approach, an organization has a clear boundary between talented and other employees, and a special approach to talented employees. The advantage of this approach can be manifested in increased attention to talented staff (an individual approach to each of them) that results in increased productivity due to the competitive environment. Among negative aspects, there is a division into groups that can endanger the self-esteem of employees who are not included in the number of "talented individuals"; nevertheless, there are very bad 
relationships between these two teams (Mousa \& Ayoubi, 2019; Schweyer, 2004; Claussen et al., 2014).

It is worth noting that each of the approaches is not mutually exclusive, but still many successful companies in the world show a tendency to an exclusive approach (General Electric, Oracle, Infosys, Microsoft, Intel, Apple, T-Mobile, Rolls-Royce, and others) than inclusive (Google, Wal-Mart, PepsiCo, Starbucks, Dell, Corning, Emirates, etc.).

Talent management, compared with personnel management, is the narrower term, with an emphasis on the exclusivity of everyone, but not on equality, as in egalitarianism. Management focuses on people rather than on the functions and emphasizes a passion in the process of talent retention (Iles et al., 2010). At the same time, responsible leadership does not play a role in mediating between inclusive and exclusive talent management (Mousa \& Ayoubi, 2019).

Within a reality in today's world, it seems appropriate to point to the development of the phenomenon of "talent" (Busarieva, 2019) in the structure of human capital management of high-tech companies. Talent management is, first of all, virtuosity as to issues of Ukraine's and foreign TNCs in their HR strategies. Increasing emphasis is being placed on the search for unique "digital talents" since they make the future of human civilization (Al-Dalahmeh et al., 2020; Gilch \& Sieweke, 2021).

In many companies, HR departments follow the path of business psychology, focusing on methods and knowledge of psychology that help the business. They do not evaluate talents from the point of view of classical psychology. TNC companies have their clear technologies developed over the years, such as "talent capital", "knowledge management", "succession planning", "career management" (career planning), "results management" (performance management), "leadership programs", "control and assessment" (applicant tracking), etc. (Barinova et al., 2020).

Despite a rather large subject area of the IT sphere, it seems appropriate to say a few words about the syndrome of professional emotional burnout. This term was first introduced by Freudenberger (1974), who made it popular. In addition, Maslach et al. (1997) researched this topic and provided a vast amount of empirical data.
Burnout syndrome is based on the nature of the individual's sphere, several symptoms, and the level of their manifestation. Thus, a modern classification has a total of 132 symptoms, divided into the following five groups: (1) affective; (2) cognitive; (3) physical; (4) behavioral; and (5) motivational. At the same time, stress and anxiety are only the beginning of serious psychiatric symptoms, except for chronic fatigue and constant exhaustion of "mental dysfunction" (Orel, 2004). According to Scherrmann (2015), lack of mental energy in IT companies is not a new phenomenon.

An exclusive approach to talent management in the psychology of innovation and personnel management of IT companies in Ukraine should focus not only on how to find talents, retain them, and provide a career, but also on how not to disturb the professional emotional balance, not to allow the employees to get depressed and leave the profession. High standards that are set for domestic staff on the example of companies in the US, Asia, and Europe are not always possible due to lack of education, experience, or inflated ambitions. Pareto Act (20/80), where 20\% of talent provides $80 \%$ of the company's revenue works in an exclusive talent management approach in reverse, Anti-Pareto Act (80/20), where $80 \%$ of talent quickly enters the stage of professional burnout, and 20\% still manage to maintain their normal professional condition. Not only the career is ruined, but also the life itself (Allied Market Research, 2021; Hennings, 2019).

\section{AIM AND HYPOTHESIS}

The aim of this study is to assess the differences in exclusive and inclusive approaches to talent management from the standpoint of the propensity of IT employees for emotional burnout.

The paper elaborated the following hypothesis to investigate these issues:

H1: There are statistically significant differences in exclusive and inclusive approaches to talent management in the psychology of innovation and personnel management of IT companies in Ukraine: the levels of professional emotional burnout in the exclusive approach are much higher. 


\section{METHODS}

This study was conducted online using Google Forms. The target group comprised multinational companies in the IT sector of Ukraine. The population of the empirical study included 70 men (46.7\%) and 80 women (53.3\%) aged 21 to 40 years. The total number of respondents is 150 employees. The respondents came from companies that use both (exclusive and inclusive) approaches to talent management. The study also included respondents from diverse age groups: 21-27 years old - 50 employees (33\%), 28-33 years old - 35 employees (23\%), 34-40 years old - 65 employees (44\%). Among them, 9 respondents are students (6\%).

The paper used the methods of Boyko (1999), namely his two questionnaires "Determining the level of emotional burnout" and "Express diagnostics of the level of emotional burnout", and Vodopyanova et al. (2013), namely their questionnaire "Professional burnout", to assess the level of professional emotional burnout among IT specialists in Ukraine.

To test the hypotheses, the study checked the indicators on the "high-level scales" as unacceptable and critical for the implementation of any further mental professional activity.

\section{RESULTS}

There is a large number of IT companies in Ukraine. According to Kulesh (2020), from 2015 to 2020, the number of IT professionals in Ukraine doubled from 90,000 to 180,000 . According to the DOU (2020) ranking, the largest IT companies in Ukraine lead in the number of employees are EPAM - 8,300 employees, SoftServe - 7,193,
GlobalLogic - 4,893, Luxoft - 3,523, and Ciklum 2,692 employees. The gender balance is changing every year; in 2020, the number of women in the IT industry increased by 79\% compared to 2015 . At that time, they accounted for only 14\% (in 2021 - 25\%) of all IT professionals. The average age of an IT specialist in 2015 was 27 , and in $2020-28$ years old.

The TOP-50 largest IT companies in Ukraine are presented in Table 1.

Table 1 shows that the IT industry has been going through hard times over the past two years, which is evidenced by the decrease in the number of working specialists (-13.75\%).

The list of IT companies of Ukraine (for 2020) that have an office only in Kyiv is presented in Table 2.

Table 2 shows that with the COVID-19 pandemic, the number of specialists employed in this area during 2019-2020 decreased markedly. According to experts' forecasts, it is only a matter of time. In the next three years, Ukrainian businessmen plan to conquer world markets, which will facilitate the search for new talents and even attract some of them from the ranks of graduate students.

The study has involved representatives of various professions of the largest IT companies in Ukraine: system administrators (10 employees, 6.7\%), DevOps-engineers (12 employees, $8 \%$ ), web software developers (16 employees, $10.7 \%$ ), database administrators (9 employees, $6 \%$ ), video game and application developers (10 employees, 6.7\%), usability specialists (UX/UI) (12 employees, 8\%), QA testers (10 employees, 6.7\%), software architects (15 employees, 10\%), web analysts (15 employees, 10\%), SEO specialists (10 employees,

Table 1. TOP-50 largest IT companies in Ukraine (2020)

\begin{tabular}{|c|c|c|c|}
\hline TOP-50 & $\begin{array}{c}\text { Specialists in } \\
\text { Ukraine }\end{array}$ & $\begin{array}{c}\Delta \\
2020 / 2019\end{array}$ & $\begin{array}{c}\text { Vacancies in } \\
\text { Ukraine }\end{array}$ \\
\hline $\begin{array}{l}\text { EPAM, SoftServe, GlobalLogic, Luxoft, Ciklum, NIX, Infopulse, DataArt, EVOPLAY, } \\
\text { Intellias, ZONE3000, ELEKS, Netcracker, Genesis, Sigma Software, Capgemini } \\
\text { Engineering Ukraine, EVO, N-iX, Lucky Labs, SQUAD, Playtika, Nexteum, Astound } \\
\text { Commerce, ISD Ltd., Ubisoft, Innovecs, Ajax Systems, Intecracy Group, Plarium, } \\
\text { Onseo, AMC Bridge, Gameloft, GeeksForLess Inc., Miratech, Parimatch Tech, } \\
\text { AUTODOC, Svitla Systems Inc, Playtech, Samsung R\&D Institute Ukraine, } \\
\text { Terrasoft, WiX, Star, Netpeak, Avenga, Oracle, Daxx, Parus, Depositphotos, } \\
\text { Intetics, MEGOGO }\end{array}$ & 76,344 & $-13.75 \%$ & 7,389 \\
\hline
\end{tabular}


Table 2. IT companies of Ukraine, founded in Kyiv (2020)

Source: Authors' elaboration.

\begin{tabular}{|c|c|c|c|}
\hline Company and its place in the ranking & Specialists in Ukraine & $\begin{array}{c}\Delta \\
2020 / 2019\end{array}$ & Vacancies in Ukraine \\
\hline EVOPLAY (9) & 2,188 & $-35.73 \%$ & 311 \\
\hline Genesis (14) & 1,536 & $-28 \%$ & 240 \\
\hline EVO (17) & 1,264 & $-18.68 \%$ & 20 \\
\hline Parimatch Tech (35) & 983 & $-12.05 \%$ & 138 \\
\hline TECHIIA Holding (27) & 890 & $-18.78 \%$ & 35 \\
\hline Intecracy Group (28) & 781 & $-3.55 \%$ & 17 \\
\hline Playtech (38) & 637 & $-3.05 \%$ & 98 \\
\hline Samsung R\&D Institute Ukraine (39) & 605 & $-10.45 \%$ & 5 \\
\hline MEGOGO (50) & 600 & $-31.58 \%$ & 34 \\
\hline Terrasoft (40) & 593 & $-3.13 \%$ & 50 \\
\hline
\end{tabular}

6.7\%), web designers (13 employees, 8.6\%), contextologists (8 employees, 5.2\%), and project managers (10 employees, 6.7\%).

Using the method of Boyko (1999), namely his questionnaire "Determining the level of emotional burnout", the paper assessed the level of emotional burnout among IT employees in Ukraine (Table 3).

Table 3. The level of professional emotional burnout of IT employees in Ukraine according to the questionnaire "Determining the level of emotional burnout"

\begin{tabular}{|c|c|c|c|}
\hline $\begin{array}{c}\text { Phases of } \\
\text { emotional } \\
\text { tension }\end{array}$ & $\begin{array}{c}\text { Employees } \\
\text { with high } \\
\text { level/\% }\end{array}$ & $\begin{array}{c}\text { Employees } \\
\text { with } \\
\text { average } \\
\text { level/\% }\end{array}$ & $\begin{array}{c}\text { Employees } \\
\text { with low } \\
\text { level/\% }\end{array}$ \\
\hline Tension & $75 / 50 \%$ & $30 / 20 \%$ & $45 / 30 \%$ \\
\hline Resistance & $30 / 20 \%$ & $75 / 50 \%$ & $45 / 30 \%$ \\
\hline Exhaustion & $60 / 40 \%$ & $45 / 29 \%$ & $46 / 31 \%$ \\
\hline In general & $54 / 36 \%$ & $51 / 34 \%$ & $45 / 30 \%$ \\
\hline
\end{tabular}

Describing the results of a survey of employees of IT companies in Ukraine using the specified method (Table 3), it is noted that the overwhelming majority of the respondents $(75 / 50 \%)$ have a high level of stress, which is characterized as the first stage on the way to the development of emotional exhaustion. The indicators of exhaustion are also quite high (60/40\%). Resistance as a phase of apposition to growing stress in half of the respondents (75/50\%) is expressed at an average level.

Summarizing the results obtained, 54 employees (36\%) of the surveyed respondents have high level of emotional burnout; at the same time, $32(21.3 \%)$ of the respondents indicated that their companies are using an exclusive approach to talent management. 51 respondents (34\%) show an average level of emotional burnout. 45 respondents $(30 \%)$ have a low level of emotional burnout.

Comparison of the responses provided by employees who come from companies using exclusive and inclusive approaches to talent management made it possible to establish that, in general, 59.2\% of the high level of professional emotional burnout of employees of IT companies occurs precisely because of the exclusive approach to talent management. Therefore, $H 1$ is confirmed.

Using the method of Boyko (1999), namely his questionnaire "Express diagnostics of the level of emotional burnout", the paper assessed the level of emotional burnout among IT employees in Ukraine (Table 4).

As can be seen from the data in Table 4, the vast majority of respondents have low and average levels of symptoms of emotional burnout. Thus, the symptom "dissatisfaction with oneself" is manifested at the average level ( 69 employees - 46\%). The symptom "being in a cage" is less pronounced among the surveyed employees of IT companies because at the average level it is manifested by 60 respondents (40\%) and at the low level - by 81 respondents (54\%). The symptom "reduction of professional responsibilities" is manifested mainly at average (75 respondents $-50 \%$ ) and low levels (60 respondents - 40\%). Emotional alienation as a symptom of emotional burnout is mostly low among the surveyed employees (75 respondents - 50\%). According to the depersonalization scale, the respondents' answers were divided into three parts (about a third for each level - high, average, and low). 
Table 4. The level of professional emotional burnout among IT employees in Ukraine according to the questionnaire "Express diagnostics of the level of emotional burnout"

Source: Authors' elaboration based on Boyko (1999).

\begin{tabular}{|c|c|c|c|}
\hline \multirow[b]{2}{*}{ Scales } & \multicolumn{3}{|c|}{ Symptom } \\
\hline & $\begin{array}{c}\text { It was folded } \\
\text { (high level), persons/\% }\end{array}$ & $\begin{array}{l}\text { It is folded (average } \\
\text { level), persons/\% }\end{array}$ & $\begin{array}{l}\text { It was not folded } \\
\text { (low level), persons/\% }\end{array}$ \\
\hline DO. Symptom "dissatisfaction with oneself" & $45 / 30 \%$ & $69 / 46 \%$ & $36 / 24 \%$ \\
\hline IC. Symptom "in a cage" & $13 / 6 \%$ & $60 / 40 \%$ & $77 / 54 \%$ \\
\hline RPD. Symptom "reduction of professional duties" & $15 / 10 \%$ & $75 / 50 \%$ & $60 / 40 \%$ \\
\hline EA. Symptom "emotional alienation" & $39 / 26 \%$ & $36 / 24 \%$ & $75 / 50 \%$ \\
\hline $\begin{array}{l}\text { PDD. Symptom "personality detachment/ } \\
\text { depersonalization" }\end{array}$ & $45 / 30 \%$ & $54 / 36 \%$ & $51 / 34 \%$ \\
\hline In general & $39 / 26 \%$ & $60 / 40 \%$ & $51 / 34 \%$ \\
\hline
\end{tabular}

Summarizing the results obtained, 39 respondents (26\%) have a high level of emotional burnout; at the same time, 26 respondents (17.3\%) indicated that they are employed at the companies that have chosen an exclusive approach to talent management. 60 (40\%) respondents are employees with an average level of emotional burnout; 51 (34\%) have a low level of emotional burnout.

Comparison of the responses provided by employees who come from companies using exclusive and inclusive approaches to talent management revealed that, in general, $66.6 \%$ of employees have a high level of professional emotional burnout; this is caused by an exclusive approach to talent management. Therefore, $\mathrm{H} 1$ is confirmed.

The study further used the method developed by Vodopyanova et al. (2013), namely their questionnaire "Professional burnout", to assess the level of professional emotional burnout among IT specialists in Ukraine (Table 5).

According to the data obtained in Table 5, it can be seen that emotional exhaustion, depersonalization, and reduction of personal achievements as indicators of emotional burnout are inherent in the respondents mainly on the average level ( $42 \%$, $40 \%$, and $40 \%$, respectively).
It can be noticed that emotional exhaustion and depersonalization are manifested at a high level by $42(28 \%)$ and $33(22 \%)$ respondents. The low level of personal achievements, which is evidence of emotional burnout, is manifested by 48 (32\%) surveyed employees of IT companies.

In addition, it is worth noting that in the general sample, $35 \%$ of men and $55 \%$ of women are in a state of feeling depleted of vital energy and intolerance of further such a destructive state. Hiding their determination and limiting themselves, they still hope to achieve their goals. In particular, these employees do some of the work and then wait for emotional improvement to solve an unsolved problem and expect a positive state again.

Summarizing the obtained results, 38 respondents (26\%) have a high level of emotional burnout; at the same time, 23 employees (15.3\%) indicated that their companies have chosen an exclusive approach to talent management. 61 respondents (41\%) are mostly employees who have an average level of emotional burnout; 51 employees (33\%) have a low level of emotional burnout.

Comparison of the responses provided by employees who come from companies using exclusive and inclusive approaches to talent management re-

Table 5. Levels of professional emotional burnout of IT employees in Ukraine according to the questionnaire "Professional burnout"

Sources: Authors' elaboration based on Vodopyanova et al. (2013).

\begin{tabular}{l|c|c|c}
\hline \multicolumn{1}{c}{ Symptoms of burning down } & $\begin{array}{c}\text { High level, } \\
\text { persons/\% }\end{array}$ & $\begin{array}{c}\text { Average level, } \\
\text { persons/\% }\end{array}$ & $\begin{array}{c}\text { Low level, } \\
\text { persons/\% }\end{array}$ \\
\hline Emotional exhaustion & $42 / 28 \%$ & $63 / 42 \%$ & $45 / 30 \%$ \\
Depersonalization & $33 / 22 \%$ & $60 / 40 \%$ & $57 / 38 \%$ \\
\hline Reduction of the personal achievements & $42 / 28 \%$ & $60 / 40 \%$ & $48 / 32 \%$ \\
\hline In general & $38 / 26 \%$ & $61 / 41 \%$ & $51 / 33 \%$ \\
\hline
\end{tabular}


vealed that, in general, $60.5 \%$ of employees show a high level of professional emotional burnout; this is mainly caused by an exclusive approach to talent management. Therefore, $\mathrm{H} 1$ is confirmed.

Detailing the results, it is noted that the representatives of the following professions were in a negative depressed state (both men and women): DevOpsengineers, project managers, system administrators, usability specialists (UX/UI), QA-testers, software developers, and software architects. New knowledge, which was acquired by the "talent pool" of IT companies from training and various courses, had to be implemented as soon as possible. Due to the aggressive model of talent management, where fines, reprimands, additional work, withdrawal of bonuses for non-compliance with the plan, etc. are applied (according to the information from forums), talents lose their potential.

The average level of emotional burnout was shown by SEO specialists, web designers, web analysts, web programmers; low-level - contextologists, and partly programmers, designers, game and application developers.

Taking into account the obtained results, the paper states that $\mathrm{H} 1$ is confirmed using three questionnaires adopted by the study. There is sufficient justification to believe that there are statistically significant differences in exclusive and inclusive approaches to talent management in the psychology of innovation and personnel management of IT companies in Ukraine: levels of professional emotional burnout of employees in an exclusive approach are much higher.

\section{DISCUSSION}

The results are consistent with the results of the previous studies, which have discussed the same topic. IT staff among others is the most exposed to occupational stress. Now in Ukraine, the most popular male professions are DevOps engineers, cybersecurity specialists, big data analysts, Python or Java developers, UX/UI designers, QA managers, system administrators, mobile application developers, Frontend developers, etc. Among the most popular female professions are contextologists, programmers, interface designers, layout designers, QA testers, web analysts, project managers, etc. Basic competencies required equally for both genders are systems thinking, environmental thinking, the use of artificial intelligence, working in conditions of uncertainty, cross-industry communication, customer focus and work in the B2B (Business-to-Business), B2G (Businessto-Government) segments, project management, multiculturalism and multilingualism (English, German, and other languages).

The findings showed empirical evidence supporting the idea that ecological practices of talent management help create a friendly and supportive work environment. Thus, the study proposes the following. Prospects for the development of IT companies in Ukraine, which have chosen an exclusive approach to talent management, are visible in the environmental use of human capital. First, in practice, the use of the achievements of neurobiology, neurophysiology, neuroethology, and unity with the innovative management of a company and personnel management is required. Second, the companies should implement achievements of the psychology of innovations, psychodiagnostic, psychology of the person, psychology of creativity in the analysis, synthesis of the information on the employees and their potential. Third, the use of anti-crisis personnel management programs in combination with psychotherapeutic techniques of a specialist, human resources development manager, IT innovation manager, is necessary.

\section{CONCLUSION}

The study aimed to assess the differences in exclusive and inclusive approaches to talent management from the standpoint of the propensity of IT employees for professional emotional burnout. The study showed a significant relationship between stress levels and the use of exclusive/inclusive approaches. According to the obtained results, more than half of the specialists in IT companies have a tendency to the average level of burnout, which is explained by the tendency of TOP-management to an exclusive 
approach to talent management. Among the negative states of the impact of this approach on the health of staff are anxiety, irritability, exhaustion, and personal alienation.

The paper adopted a comprehensive technique to examine the interconnections between the talent management model and the level of employee productivity; the talent management model and psycho-physiological reserves of personality; job satisfaction and stress. As for further studies, it is suggested to conduct a similar analysis in the medical sphere (among physicians of cybernetics, clinical bioinformatics, biopharmacologists, etc.).

\section{AUTHOR CONTRIBUTIONS}

Conceptualization: Natalia Nosan.

Data curation: Natalia Nosan.

Formal analysis: Natalia Nosan.

Investigation: Natalia Nosan.

Methodology: Sergiy Nazarenko.

Project administration: Natalia Nosan.

Resources: Natalia Nosan.

Software: Sergiy Nazarenko.

Supervision: Sergiy Nazarenko.

Validation: Natalia Nosan.

Visualization: Natalia Nosan.

Writing - original draft: Natalia Nosan, Sergiy Nazarenko.

Writing - review \& editing: Natalia Nosan, Sergiy Nazarenko.

\section{REFERENCES}

1. Al Ariss, A. (2014). Global talent management: an introduction and a review. In $\mathrm{A}$. $\mathrm{Al}$ Ariss (Ed.), Global Talent Management. Management for Professionals (pp. 3-13). Cham: Springer. https://doi org/10.1007/978-3-319-05125-3_1

2. Al-Dalahmeh, M., Héder-Rima, M., \& Dajnoki, K. (2020). The effect of talent management practices on employee turnover intention in the Information and Communication Technologies (ICTs) sector: case of Jordan. Problems and Perspectives in Management, 18(4), 59-71. http://dx.doi. org/10.21511/ppm.18(4).2020.06

3. Allied Market Research. (2021). Workplace Stress Management Market by Service. Retrieved from https://www.alliedmarketresearch. com/workplace-stress-management-market-A11102

4. Barinova, E. P., Sheremetyeva, E. N., \& Zotova, A. S. (2020). Digital Talents: Realities and Prospects. Springer.
5. Becker, G. S. (1993). Human Capital: A Theoretical and Empirical Analysis, With Special Reference to Education. University of Chicago Press.

6. Berseneva, E. I., Buzan, O. N., Lysenko, K. K., Hismatullina, K., \& Capodoy, E. A. (2019). Talent Management as a New Concept of Human Resource Management: A Comparative Analysis of "Best Practices". Management Of The Personnel And Intellectual Resources In Russia, 8(4), 74-82. https://doi.org/10.12737/article_5 d7b9b8ce29f03.60059687

7. Boštjančičč, E., \& Slana, Z. (2018). The role of talent management comparing medium-sized and large companies - major challenges in attracting and retaining talented employees. Frontiers in Psychology, 9, 1750. https://doi. org/10.3389/fpsyg.2018.01750

8. Boyko, V. (1999). Metodika diagnostiki urovnya emotsionalnogo vygoraniya [A method of assessing the severity of burnout syndrome]. In D. Ya. Raygorodskiy (Ed.), Prakticheskaya psikhodiagnostika. Metodiki i testy - Practical Psychodiagnostics: Methodology of tests (pp. 161-169). Samara. (In Russian). Retrieved from http://www. miu.by/kaf_new/mpp/032.pdf

9. Busarieva, T. (2019). Talantism in the structure of the human capital management of TNC. Problems of system approach in economy, 2(1), 7-13. https://doi. org/10.32782/2520-2200/2019-2-1

10. Cascio, W. F., \& Boudreau, J. W. (2016). The search for global competence: From international HR to talent management. Journal of World Business, 51(1), 103114. https://doi.org/10.1016/j. jwb.2015.10.002

11. Chamorro-Premuzic, T., Swami, V., \& Cermakova, B. (2012). Individual differences in music consumption are predicted by uses of music and age rather than emotional intelligence, 
neuroticism, extraversion or openness. Psychology of Music, 40(3), 285-300. https://doi. org/10.1177/0305735610381591

12. Claussen, J., Grohsjean, T., Luger, J., \& Probst, G. (2014). Talent management and career development: What it takes to get promoted. Journal of World Business, 49(2), 236-244. https://doi. org/10.1016/j.jwb.2013.11.007

13. DOU. (2020). TOP-50 naibilshykh IT-kompanii Ukrainy - Sichen 2020 [The TOP-50 largest IT companies in Ukraine - January 2020]. (In Ukrainian). Retrieved from https://jobs.dou.ua/top50/ january-2020/

14. DOU. (2021). TOP-50 naibilshykh IT-kompanii Ukrainy - Sichen 2021 [The TOP-50 largest IT companies in Ukraine - January 2021]. (In Ukrainian). Retrieved from https://jobs.dou.ua/top50/ january-2021/

15. Dries, N. (2013). Talent management, from phenomenon to theory: introduction to the special issue. Human Resource Management Review, 23(4), 267-271. https://doi. org/10.1016/j.hrmr. 2013.08.006

16. Freudenberger, H. (1974). Staff burn-out. Journal of Social Issues, 30(1), 159-165. http://dx.doi. org/10.1111/j.1540-4560.1974. tb00706.x

17. Gilch, P. M., \& Sieweke, J. (2021). Recruiting digital talent: The strategic role of recruitment in organisations' digital transformation. German Journal of Human Resource Management, 35(1), 53-82. https://doi. org/10.1177/2397002220952734

18. Hennings, M. (2019). What Millennials Want from Work: How to Maximize Engagement in Today's Workforce. Asia Pacific Business Review, 25(1), 149-151. https:// doi.org/10.1080/13602381.2018.1 494781

19. Iles, P., Chuai, X., \& Preece, D. (2010). Talent management and HRM in multinational companies in Beijing: definitions, differences and drivers. Journal of World Business, 45(2), 179-189. https://doi. org/10.1016/j.jwb.2009.09.014
20. InVenture. (2021). Reyting TOP50 krupneyshiye IT-kompanii v Ukraine [The TOP-50 largest IT companies in Ukraine]. (In Russian). Retrieved from https://bit. ly/38eZSGp

21. Kashlakova, A. (2021). Definitsiia "Talantu" V Systemi Upravlinnia Talantamy. Dialektychnyi Analiz [Definition of "talent" in the talent management system. Dialectic analysis]. Naukovi perspektivi - Scientific Prospects, 9(15). (In Ukrainian). https://doi. org/10.52058/2708-7530-20219(15)-111-119

22. Kovalska, K., \& Kovaliukh, Ye. (2019). Faktory I Pokaznyky Efektyvnosti Systemy Talant-Menedzhmentu V Orhanizatsiiakh [Factors and indicators of the effectiveness of the talent management system in organizations]. Young Scientist, 4(68), 173-177. (In Ukrainian). https://doi.org/10.32839/23045809/2019-4-68-41

23. Kulesh, S. (2020, September 11). Issledovaniye: $Z$ a 5 let kolichestvo IT-spetsialistov $v$ Ukraine vyroslo vdvoye, a zhenshchin v IT - na 79\% [A study: Over 5 years the number of IT specialists in Ukraine has doubled, and the number of women in IT increased by 79\%]. ITC. (In Russian). Retrieved from https://itc.ua/news/issledovanieza-5-let-kolichestvo-it-speczialistov-v-ukraine-vyroslo-vdvoe-azhenshhin-v-it-na-79/

24. Kuznetsova, N. (2014). Kontseptsiia Upravlinnia Talantamy V Systemi Menedzhmentu Znan [The concept of talent management in the knowledge management system]. Sotsialno-trudovi vidnosyny: teoriia ta praktyka - Social and labor relations: theory and practice, 2(8), 181-187. (In Ukrainian). Retrieved from http:// projects.dune-hd.com/bitstream/ handle/2010/5887/181-187. pdf? sequence $=1$ \&isAllowed $=y$

25. Lewis, R. E., \& Heckman, R. J. (2006). Talent management: A critical review. Human Resource Management Review, 16(2), 139154. https://doi.org/10.1016/j. hrmr.2006.03.001

26. Marinakou, E., \& Giousmpasoglou, C. (2019). Talent manage- ment and retention strategies in luxury hotels: evidence from four countries. International Journal of Contemporary Hospitality Management, 31(10), 38553878. https://doi.org/10.1108/ IJCHM-10-2018-0862

27. Maslach, C., Jackson, S. E., \& Leiter, M. P. (1997). The Maslach Burnout Inventory Manual. In Maslach Burnout Inventory (pp. 191-218). Mountain View. Retrieved from https://bit. ly/3FAcBCs

28. Michaels, E., Handfield-Jones, H., \& Axelrod, B. (2001). The war for talent. Boston, Massachusetts: Harvard Business School Press. Retrieved from https://www. worldcat.org/title/war-for-talent/ oclc/46835605

29. Miller, A., \& Yakovleva, E. (2021). Influence of Intellectual Infrastructure of Technological Development on the Personnel Management System at Industrial Enterprise. IOP Conference Series: Earth and Environmental Science, 678, 012038. https://doi.org/10.1088/17551315/678/1/012038

30. Mousa, M., \& Ayoubi, R. M. (2019). Inclusive/exclusive talent management, responsible leadership and organizational downsizing: A study of academics in Egyptian public business schools. Journal of Management Development, 38(2), 87-104. https://doi. org/10.1108/JMD-11-2018-0325

31. Nguyen, D. T. N., \& Teo, S. T. T. (2018). HR orientations and HR department effectiveness in Vietnam. Personnel Review, 47(5), 1043-1061. https://doi. org/10.1108/PR-03-2017-0074

32. Orel, V. (2014). Sindrom psikhicheskogo vygoraniya: mify i realnost [Mental burnout syndrome: myths and reality]. Institute of Applied Psychology "Humanitarian centre". (In Russian).

33. Ready, D. A. (2007). Make your company a talent factory. Human Resource Management International Digest, 15(7). https://doi.org/10.1108/ HRMID.2007.04415GAD.005

34. Savanevičienè, A., \& Vilčiauskaitè, 
B. (2017). Practical Application of Exclusive and Inclusive Talent Management Strategy in Companies. Business Management and Education, 15(2), 242-260. Retrieved from https:// www.ceeol.com/search/articledetail $? \mathrm{id}=677709$

35. Scherrmann, U. (2015) Burnout-Faktoren in einem Organisationsmodell der systemischen Organisationsentwicklung. In Stress und Burnout in Organisationen (pp. 57-65). Springer, Berlin, Heidelberg. (In German). https:// doi.org/10.1007/978-3-662-455364_9

36. Schweyer, A. (2004). Talent Management Systems: Best Practices in Technology Solutions for Recruitment, Retention and Workforce Planning. John Wiley \& Sons.

37. Shchokina, Yu., Zadorozhniuk, N., \& Biloysova, I. (2020). Systema Upravlinnia Talantamy V Suchasnykh Orhanizatsiiakh [Talent management system in modern organizations]. Infrastruktura Rynku - Market infrastructure, 43, 347-351. (In Ukrainian). Retrieved from http://www.market-infr. od.ua/journals/2020/43_2020_ ukr/65.pdf

38. Shortlister. (2021). 55 Troubling Workplace Stress Statistics for 2021. Retrieved from https:// www.myshortlister.com/insights/ workplace-stress-statistics

39. Storozhuk, A., \& Zaiarniuk, O. (2019). Motyvatsiia personalu yak osnova talant-menedzhmentu v innovatsiino-intehrovanykh strukturakh [Staff Motivation as a Basis for Talent Management in Innovative and Integrated Structures]. Tsentralnoukrainskyi naukovyi visnyk. Ekonomichni nauky - Central Ukrainian Scientific Bulletin. Economic Sciences, 2(35), 115-123. (In Ukrainian). Retrieved from https://www.ceeol.com/search/ article-detail?id=806231

40. Tansley, C. (2011). What do we mean by the term "talent" in talent management? Industrial and Commercial Training, 43(5), 266-274. https://doi. org/10.1108/00197851111145853
41. Vodopyanova, N., Starchenkova, E., \& Nasledov, A. (2013). Standartizirovannyy oprosnik "Professionalnoye vygoraniye" dlya spetsialistov sotsionomicheskikh professiy [Standardized questionnaire "Professional burnout" for specialists in socionomic professions]. Vestnik Sankt-Peterburgskogo universiteta. Sotsiologiya Bulletin of St. Petersburg University. Sociology, 4, 17-27. (In Russian). Retrieved from https://cyberleninka.ru/article/n/16062789

42. Vynnychuk, R. (2017). Osoblyvosti Pidboru Personalu V Systemi Talant-Menedzhmentu Orhanizatsii [Features Of Recruitment In The Talent-Management System Of Organization]. Visnyk ONU imeni I. I. Mechnykova - Bulletin of ONU named after I.I. Mechnikov, 22(2(55)), 130-133. (In Ukrainian). Retrieved from https://bit. ly/30DuBfL

43. Watkins, D. (1998). Lightyear: An Application Framework for Talent Management That Acts as a Central Feedback Center for all Organizational Functions. Softscape, Incorporated. 